\title{
Unravelling the Potential for Dithienopyrrole Sensitizers in Dye- Sensitized Solar Cells
}

Lauren E. Polander, ${ }^{* \dagger}$ Aswani Yella, ${ }^{\dagger}$ Joël Teuscher, ${ }^{\dagger}$ Robin Humphry-Baker, ${ }^{\dagger}$ Basile F. E. Curchod, ${ }^{\ddagger}$ Negar Ashari Astani, ${ }^{\ddagger}$ Peng Gao, ${ }^{\dagger}$ Jacques-E. Moser, ${ }^{\S}$ Ivano Tavernelli, ${ }^{\ddagger}$ Ursula Rothlisberger, ${ }^{\ddagger}$ Michael Grätzel, ${ }^{\dagger}$ Md. Khaja Nazeeruddin, ${ }^{*}{ }^{\dagger}$ and Julien Frey ${ }^{\dagger}$

${ }^{\dagger}$ Laboratory of Photonics and Interfaces, ${ }^{\ddagger}$ Laboratory of Computational Chemistry and Biochemistry, and ${ }^{\S}$ Group for Photochemical Dynamics, Institute of Chemical Sciences and Engineering, School of Basic Sciences, École Polytechnique Fédérale de Lausanne, CH-1015 Lausanne, Switzerland

Supporting Information

ABSTRACT: Two D- $\pi-A$ dyes based on the dithieno $\left[3,2-b: 2^{\prime}, 3^{\prime}-d\right]$ pyrrole $\pi$-bridge (DTP) were synthesized, characterized using UV-vis absorption spectroscopy and electrochemistry, modeled using quantum chemical calculations, and used as sensitizers in dye-sensitized solar cells (DSCs). The photoelectrochemical properties and DSC performance are thoroughly compared with their cyclopenta[1,2-b:5,4- $\left.b^{\prime}\right]$ dithiophene (CPDT) analogues. The use of DTP results in a small increase in the zero-zero transition energy reflecting the higher lying lowest unoccupied molecular orbital that is commonly reported for DTP relative to CPDT systems. This increased optical gap manifests in slightly blue-shifted incident photon-to-collected

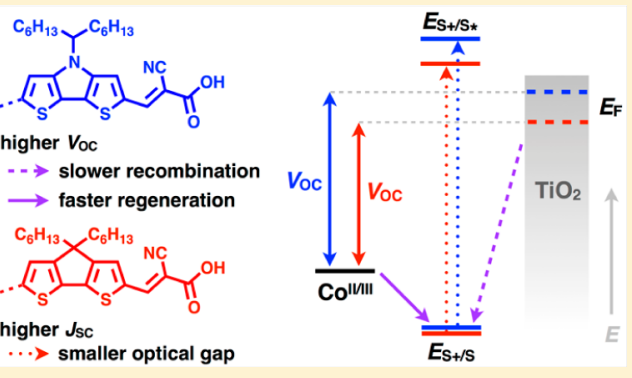
electron conversion efficiency (IPCE) responses; however, increased opencircuit photovoltage values and improved charge-transfer kinetics relative to the CPDT systems result in comparable power conversion efficiencies. The present report highlights the potential of DTP for the development of tailored sensitizers employing stronger acceptors.

KEYWORDS: dye-sensitized solar cells, $D-\pi-A$, dithienopyrrole

\section{INTRODUCTION}

Over the past two decades, considerable research efforts have been devoted to dye-sensitized solar cells (DSCs) due to their potential as a low-cost photovoltaic technology. ${ }^{1}$ The basic working principle, which relies on a delicate energetic balance between the anode, sensitizer, and electrolyte, is comprehensively described in a review by Hagfeldt et al. ${ }^{2}$ The most efficient cells are based on relatively expensive or synthetically challenging ruthenium(II) and porphyrin sensitizers that have provided efficiencies up to $11.7 \%$ and $11.9 \%$, respectively. ${ }^{3,4}$

More accessible organic dyes take the form of a $\mathrm{D}-\pi-\mathrm{A}$ structure, which is reminiscent of push-pull chromophores used in nonlinear optics. ${ }^{5}$ In this context, oligothiophenes and their fused derivatives are intensively exploited as $\pi$-bridges. ${ }^{6}$ The two highest performing organic dyes, Y123 and JF419 (Chart 1), incorporate cyclopenta $\left[1,2-b: 5,4-b^{\prime}\right]$ dithiophene (CPDT), reaching power conversion efficiencies of up to $10.3 \%{ }^{7,8}$ The success of CPDT is attributed to (i) the advantageous steric effect of the alkyl groups placed in the 4,4position, which helps to prevent aggregation of the dyes on the surface, and (ii) the effective electronic communication between the donor (D) and acceptor (A), which enables efficient charge transfer.

Contrary to the CPDT bridge, which is synthetically costly

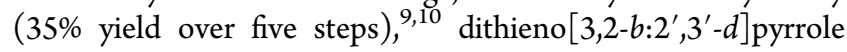

(DTP) is more accessible (up to $80 \%$ yield in one step) as showcased by Rasmussen et al. ${ }^{11,12}$ Notably, N-substituted DTP possesses similar electronic properties with respect to $\mathrm{CPDT}^{13}$ but also has the potential to incorporate a variety of $\mathrm{N}$-substituents. As a result, this position offers greater versatility toward the control of dye aggregation, which makes it particularly attractive for DSC applications. ${ }^{14,15}$

The only direct comparison between CPDT and DTP $\pi$ bridges in sensitizers for DSCs concluded that the latter exhibits (i) faster recombination of electrons injected into $\mathrm{TiO}_{2}$ to the electrolyte and (ii) slower regeneration of the oxidized dye by the electrolyte. ${ }^{16}$ These issues can be addressed through the insulation of the $\mathrm{TiO}_{2}$ surface and by choosing the appropriate cobalt(II/III) redox mediator, respectively. ${ }^{17}$

Herein, we demonstrate the full potential for DTP as an effective $\pi$-bridge using the two principles outlined above. Although a variety of primary amines are compatible with the DTP synthesis, a branched $N$-alkyl substitution was selected in this study to mimic the steric properties of the CPDT bridge. The LP225 and LP227 sensitizers were modeled after Y123 and JF419; they incorporate dialkyoxy-substituted biphenyl

Received: April 10, 2013

Revised: June 1, 2013

Published: June 27, 2013 
Chart 1. Structures of DTP-Based Dyes, LP225 and LP227, along with Their CPDT-Based Analogues, Y123 and JF419

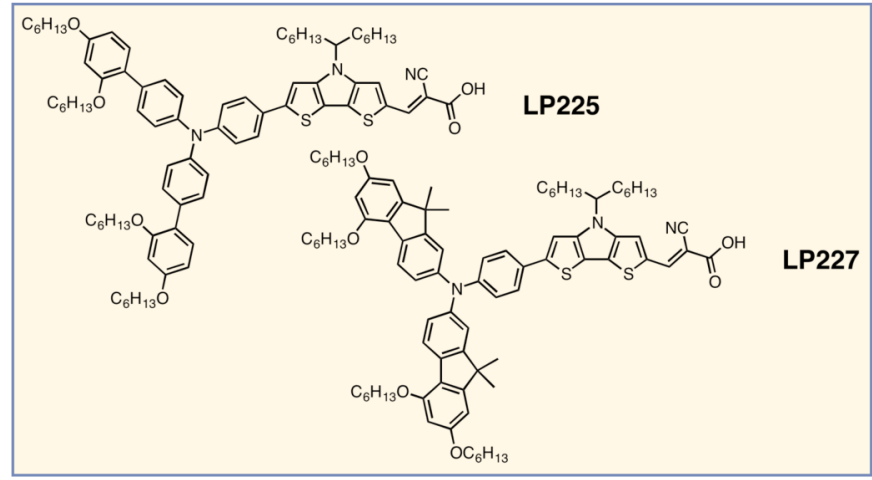

$(\mathrm{D} 1)^{6,17}$ and fluorene $(\mathrm{D} 2)^{8}$ donors that are known to reduce charge recombination in the device by preventing the oxidized redox mediator to access the $\mathrm{TiO}_{2}$ surface (Chart 1). Additionally, the dyes were tested in DSCs using a mixture of tris $\left(2,2^{\prime}\right.$-bipyridine $)$ cobalt(II) and tris $\left(2,2^{\prime}\right.$-bipyridine $)$ cobalt(III) complexes $\left(\left[\mathrm{Co}^{\mathrm{II} / \mathrm{III}}(\mathrm{bpy})_{3}\right]^{2+/ 3+}\right.$, see Experimental Details for full electrolyte composition), which provides ample driving force for oxidized dye regeneration, resulting in quantitative regeneration yields and efficiencies up to $8.7 \%{ }^{18}$

\section{EXPERIMENTAL DETAILS}

Materials. Starting materials were reagent grade and were used without further purification. Solvents were obtained as anhydrous grade from Acros Organics (toluene, THF, DMF). Compound 1, 3,3'dibromo-2,2'-bithiophene, was purchased from Sigma-Aldrich. The 4,4,5,5-tetramethyl-1,3,2-dioxaborolane derivatives of $\mathrm{D} 1^{19}$ and $\mathrm{D} 2,{ }^{8}$ referred to as D1-bpin and D2-bpin, were synthesized according to reported procedures. Compound numbering is based on Scheme 1.

Scheme 1. Synthesis of LP225 and LP227 ${ }^{a}$

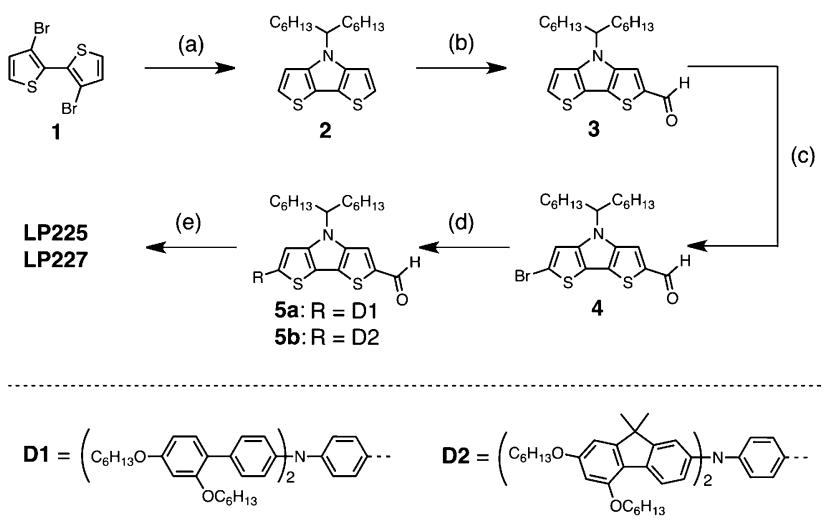

${ }^{a}$ (a) $\mathrm{Pd}_{2} \mathrm{dba}_{3}, \mathrm{BINAP}, \mathrm{NaO}^{\mathrm{t}} \mathrm{Bu}$, toluene, reflux; 74\%. (b) i. LDA, THF, $-78{ }^{\circ} \mathrm{C}$; ii. DMF, $-78{ }^{\circ} \mathrm{C}$ to $\mathrm{rt}$; $72 \%$. (c) NBS, THF, $-78{ }^{\circ} \mathrm{C}$ to rt; $84 \%$. (d) Dioxaborolane derivative of $\mathrm{D} 1$ or $\mathrm{D} 2, \mathrm{Pd}\left(\mathrm{PPh}_{3}\right)_{4}, \mathrm{~K}_{2} \mathrm{CO}_{3}$, THF, reflux; 93\%. (e) Cyanoacetic acid, piperidine, $\mathrm{CHCl}_{3}$, reflux; 90-93\%.

Chromatographic separations were performed according to standard flash column chromatography methods using silica (Merck: silica gel 60, 230-400 mesh ASTM). Analytical thin-layer chromatography (TLC) was performed on aluminum-backed sheets precoated with silica 60 F254 adsorbent ( $0.25 \mathrm{~mm}$ thick; Merck, Germany) and visualized under UV light (254 and $365 \mathrm{~nm})$.

Characterization. ${ }^{1} \mathrm{H}$ and ${ }^{13} \mathrm{C}$ NMR were recorded at 400 and 100 $\mathrm{MHz}$, respectively, on a Bruker AV 400 instrument at ambient temperature. Elemental analysis (EA), electrospray ionization (ESI),

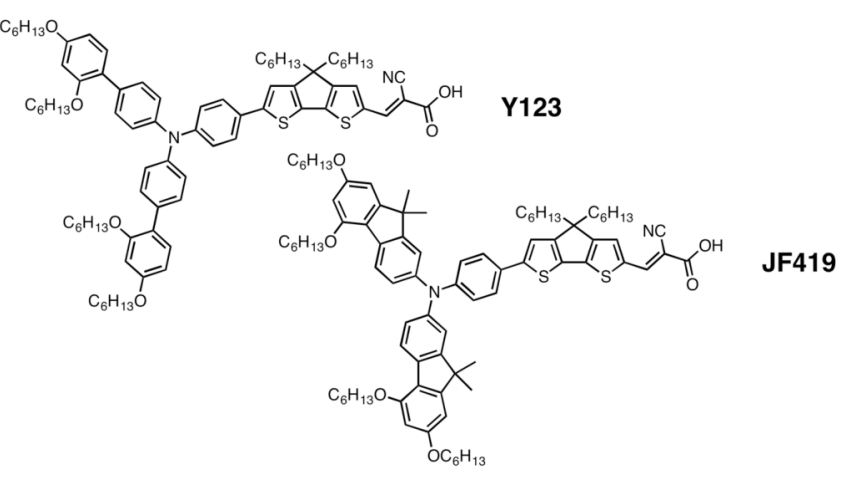

and matrix-assisted laser desorption ionization (MALDI) mass spectrometry data were collected at the École Polytechnique Fédérale de Lausanne (EPFL).

Compound 2. A solution of $\mathbf{1}(0.250 \mathrm{~g}, 0.771 \mathrm{mmol})$, flame-dried sodium tert-butoxide $(0.222 \mathrm{~g}, 2.31 \mathrm{mmol})$, tris(dibenzylideneacetone)dipalladium $\left(\mathrm{Pd}_{2}(\mathrm{dba})_{3}, 0.018 \mathrm{~g}, \quad 0.019\right.$ mmol), and 2,2'-bis(diphenylphosphino)-1,1'-binaphthyl (BINAP, $0.048 \mathrm{~g}, 0.077 \mathrm{mmol})$ in dry toluene $(1.5 \mathrm{~mL})$ was purged with nitrogen. After $20 \mathrm{~min}$, tridecan-7-amine $(0.154 \mathrm{~g}, 0.771 \mathrm{mmol})$ was added, and the mixture was stirred overnight at $120{ }^{\circ} \mathrm{C}$. Upon completion by TLC $(18 \mathrm{~h})$, the reaction mixture was diluted with hexanes and filtered through silica gel eluting with hexanes followed by $2 \%$ ethylacetate in hexanes. The solvent was removed under reduced pressure, and the crude product was purified by flash chromatography (silica gel, $2 \%$ ethylacetate in hexanes) to yield slightly yellow solid $(0.206 \mathrm{~g}, 0.571 \mathrm{mmol}, 74 \%) .{ }^{1} \mathrm{H}$ NMR $\left(400 \mathrm{MHz}, \mathrm{CDCl}_{3}\right) \delta 7.08$ (d, $J$ $=5.6 \mathrm{~Hz}, 1 \mathrm{H}), 7.00(\mathrm{~d}, J=5.2 \mathrm{~Hz}, 1 \mathrm{H}), 4.19(\mathrm{tt}, J=10.0,5.0 \mathrm{~Hz}, 1 \mathrm{H})$, $2.08-1.92(\mathrm{~m}, 2 \mathrm{H}), 1.88-1.72(\mathrm{~m}, 2 \mathrm{H}), 1.30-1.06(\mathrm{~m}, 14 \mathrm{H}), 1.06-$ $0.92(\mathrm{~m}, 2 \mathrm{H}), 0.79(\mathrm{t}, J=7.0 \mathrm{~Hz}, 6 \mathrm{H}) .{ }^{13} \mathrm{C}\left\{{ }^{1} \mathrm{H}\right\}$ NMR $(100 \mathrm{MHz}$, $\left.\mathrm{CDCl}_{3}\right) \delta 144.1,122.3,114.7,111.8,59.8,35.1,31.5,28.9,26.5,22.5$, 14.0. HRMS (EI): $m / z$ calcd for $\mathrm{C}_{21} \mathrm{H}_{31} \mathrm{NS}_{2}\left(\mathrm{M}^{+}\right): 361.1898$. Found: 361.1896. Anal. Calcd. for $\mathrm{C}_{21} \mathrm{H}_{31} \mathrm{NS}_{2}$ : C, 69.75; H, 8.64; N, 3.87 . Found: C, 69.75; H, 8.71; N, 3.83 .

Compound 3. A solution of $2(0.800 \mathrm{~g}, 2.21 \mathrm{mmol})$ in dry THF $(22 \mathrm{~mL})$ was cooled to $-78{ }^{\circ} \mathrm{C}$ under nitrogen. After $20 \mathrm{~min}$, freshly prepared lithium diisopropylamine (LDA, $0.237 \mathrm{~g}, 2.21 \mathrm{mmol}$ ) was added dropwise, and the mixture was stirred for $2 \mathrm{~h}$ at $-78{ }^{\circ} \mathrm{C}$. Dimethylformamide $(0.162 \mathrm{~g}, 2.21 \mathrm{mmol})$ was added dropwise, and the mixture was allowed to warm to room temperature for $1 \mathrm{~h}$. The reaction mixture was then poured into water, and the organic portions were extracted with dichloromethane, dried over $\mathrm{MgSO}_{4}$, and filtered. The solvent was removed under reduced pressure, and the crude product was purified by flash chromatography (silica gel, 1:1 hexanes/ dichloromethane). Two bands were collected, which corresponded to unreacted starting material 2 ( $0.156 \mathrm{~g}, 0.431 \mathrm{mmol}, 20 \%$ recovered starting material $)$ and the desired product as an orange solid $(0.620 \mathrm{~g}$, $1.59 \mathrm{mmol}, 72 \%) .{ }^{1} \mathrm{H}$ NMR (400 MHz, $\left.\mathrm{CDCl}_{3}\right) \delta 9.86(\mathrm{~s}, 1 \mathrm{H}), 7.65$ $(\mathrm{s}, 1 \mathrm{H}), 7.34(\mathrm{~d}, J=5.6 \mathrm{~Hz}, 1 \mathrm{H}), 7.01(\mathrm{~d}, J=5.6 \mathrm{~Hz}, 1 \mathrm{H}), 4.22(\mathrm{tt}, J=$ $10.0,5.0 \mathrm{~Hz}, 1 \mathrm{H}), 2.08-1.93(\mathrm{~m}, 2 \mathrm{H}), 1.92-1.78(\mathrm{~m}, 2 \mathrm{H}), 1.30-1.06$ $(\mathrm{m}, 14 \mathrm{H}), 1.06-0.92(\mathrm{~m}, 2 \mathrm{H}), 0.79(\mathrm{t}, J=7.0 \mathrm{~Hz}, 6 \mathrm{H}) .{ }^{13} \mathrm{C}\left\{{ }^{1} \mathrm{H}\right\}$ NMR $\left(100 \mathrm{MHz}, \mathrm{CDCl}_{3}\right) \delta 183.1,148.5,143.4,139.9,128.3,123.5$, $120.3,115.1,111.7,60.3,35.1,31.6,28.9,26.6,22.5,14.0$. HRMS (ESI): $m / z$ calcd for $\mathrm{C}_{22} \mathrm{H}_{32} \mathrm{NOS}_{2}\left([\mathrm{M}+\mathrm{H}]^{+}\right): 390.1925$. Found: 390.1920. Anal. Calcd. for $\mathrm{C}_{22} \mathrm{H}_{31} \mathrm{NOS}_{2}$ : C, 67.82; H, 8.02; N, 3.59. Found: C, 67.86; H, 8.22; N, 3.53.

Compound 4. A solution of $3(0.500 \mathrm{~g}, 1.28 \mathrm{mmol})$ in THF $(25$ $\mathrm{mL}$ ) was covered with foil and cooled to $-78{ }^{\circ} \mathrm{C}$ in a dry ice/acetone bath. $\mathrm{N}$-Bromosuccinimide (NBS, $0.228 \mathrm{~g}, 1.28 \mathrm{mmol}$ ) was added, and the mixture was stirred at $-78{ }^{\circ} \mathrm{C}$. After $30 \mathrm{~min}$, the mixture was slowly warmed to room temperature, and the solvent was removed under reduced pressure. The crude product was purified by passing through a plug of silica gel eluting with dichloromethane to yield the product as an orange solid ( $0.505 \mathrm{~g}, 1.08 \mathrm{mmol}, 84 \%) .{ }^{1} \mathrm{H}$ NMR (400 
$\left.\mathrm{MHz}, \mathrm{CDCl}_{3}\right) \delta 9.85(\mathrm{~s}, 1 \mathrm{H}), 7.63(\mathrm{~s}, 1 \mathrm{H}), 7.07(\mathrm{~s}, 1 \mathrm{H}), 4.15(\mathrm{tt}, J=$ $10.0,5.0 \mathrm{~Hz}, 1 \mathrm{H}), 2.02-1.90(\mathrm{~m}, 2 \mathrm{H}), 1.90-1.78(\mathrm{~m}, 2 \mathrm{H}), 1.30-1.06$ (m, $14 \mathrm{H}), 1.06-0.92(\mathrm{~m}, 2 \mathrm{H}), 0.80(\mathrm{t}, J=7.0 \mathrm{~Hz}, 6 \mathrm{H}) .{ }^{13} \mathrm{C}\left\{{ }^{1} \mathrm{H}\right\}$ NMR $\left(100 \mathrm{MHz}, \mathrm{CDCl}_{3}\right) \delta 183.0,145.9,142.4,140.3,123.1,120.1$, 115.4, 115.2, 115.0, 60.5, 35.1, 31.5, 28.9, 26.6, 22.5, 14.0. HRMS (ESI): $m / z$ calcd for $\mathrm{C}_{22} \mathrm{H}_{31} \mathrm{BrNOS}_{2}\left([\mathrm{M}+\mathrm{H}]^{+}\right): 468.1030$. Found: 468.1042. Anal. Calcd. for $\mathrm{C}_{22} \mathrm{H}_{30} \mathrm{BrNOS}_{2}$ : C, 56.40; H, 6.45; N, 2.99 . Found: C, 56.40; H, 6.69; N, 2.97.

Compound 5a. A solution of $4(0.048 \mathrm{~g}, 0.103 \mathrm{mmol}), \mathrm{D} 1-\mathrm{bpin}^{19}$ $(0.100 \mathrm{~g}, 0.108 \mathrm{mmol})$, and $\mathrm{Pd}\left(\mathrm{PPh}_{3}\right)_{4}(0.012 \mathrm{~g}, 0.010 \mathrm{mmol})$ in THF $(5 \mathrm{~mL})$ was degassed with nitrogen. A $2 \mathrm{M}$ aqueous solution of $\mathrm{K}_{2} \mathrm{CO}_{3}$ $(0.5 \mathrm{~mL})$ was added, and the mixture was heated to $70{ }^{\circ} \mathrm{C}$ overnight. The reaction mixture was quenched with water, and the organic portions were extracted with dichloromethane, washed with brine, and dried over $\mathrm{MgSO}_{4}$. The drying agent was removed via filtration, and the solvent was removed under reduced pressure. The crude product was purified by flash chromatography (silica gel, 1:1 dichloromethane/ hexanes) to yield an orange solid $(0.114 \mathrm{~g}, 0.096 \mathrm{mmol}, 93 \%) .{ }^{1} \mathrm{H}$ $\operatorname{NMR}\left(400 \mathrm{MHz}, \mathrm{CDCl}_{3}\right) \delta 9.83(\mathrm{~s}, 1 \mathrm{H}), 7.61(\mathrm{~s}, 1 \mathrm{H}),, 7.51(\mathrm{~d}, J=8.7$ $\mathrm{Hz}, 2 \mathrm{H}), 7.45(\mathrm{~d}, J=8.7 \mathrm{~Hz}, 4 \mathrm{H}), 7.25(\mathrm{~d}, J=8.7 \mathrm{~Hz}, 2 \mathrm{H}), 7.17(\mathrm{~m}$, $6 \mathrm{H}), 7.12(\mathrm{~s}, 1 \mathrm{H}), 6.57-6.48(\mathrm{~m}, 4 \mathrm{H}), 4.22(\mathrm{tt}, J=10.0,5.0 \mathrm{~Hz}, 1 \mathrm{H})$, $3.97(\mathrm{t}, J=6.7 \mathrm{~Hz}, 4 \mathrm{H}), 3.95(\mathrm{t}, J=6.6 \mathrm{~Hz}, 4 \mathrm{H}), 2.09-1.96(\mathrm{~m}, 2 \mathrm{H})$, $1.92-1.83(\mathrm{~m}, 2 \mathrm{H}), 1.83-1.68(\mathrm{~m}, 8 \mathrm{H}), 1.50-1.43(\mathrm{~m}, 4 \mathrm{H}), 1.43-$ $1.37(\mathrm{~m}, 4 \mathrm{H}), 1.37-1.32(\mathrm{~m}, 8 \mathrm{H}), 1.32-1.25(\mathrm{~m}, 10 \mathrm{H}), 1.25-1.09$ $(\mathrm{m}, 14 \mathrm{H}), 0.90(\mathrm{t}, J=7.1 \mathrm{~Hz}, 6 \mathrm{H}), 0.86(\mathrm{t}, J=7.0 \mathrm{~Hz}, 6 \mathrm{H}), 0.79(\mathrm{t}, J=$ $6.9 \mathrm{~Hz}, 6 \mathrm{H}) .{ }^{13} \mathrm{C}\left\{{ }^{1} \mathrm{H}\right\} \mathrm{NMR}\left(100 \mathrm{MHz}, \mathrm{CDCl}_{3}\right) \delta 182.8,159.6,157.0$, $148.1,147.5,145.4,139.5,133.6,130.9,130.3,128.2,126.5,124.1$, $123.2,122.9,113.7,106.2,105.3,100.4,68.4,68.2,60.3,35.1,31.7$, 31.6, 31.5, 29.5, 29.4, 29.1, 29.0, 26.6, 25.8, 22.73, 22.66, 22.6, 22.5, $14.1,14.0$ (four aromatic resonances not observed due to overlap). HRMS (ESI): $m / z$ calcd for $\mathrm{C}_{76} \mathrm{H}_{101} \mathrm{~N}_{2} \mathrm{O}_{5} \mathrm{~S}_{2}\left([\mathrm{M}+\mathrm{H}]^{+}\right): 1185.7152$. Found: 1185.7114. Anal. Calcd. for $\mathrm{C}_{76} \mathrm{H}_{100} \mathrm{~N}_{2} \mathrm{O}_{5} \mathrm{~S}_{2}: \mathrm{C}, 76.98 ; \mathrm{H}, 8.50$; N, 2.36. Found: C, 77.27; H, 8.82; N, 2.25 .

Compound 5b. A solution of $4(0.044 \mathrm{~g}, 0.095 \mathrm{mmol}), \mathrm{D} 2-\mathrm{bpin}^{8}$ $(0.100 \mathrm{~g}, 0.100 \mathrm{mmol})$, and $\mathrm{Pd}\left(\mathrm{PPh}_{3}\right)_{4}(0.012 \mathrm{~g}, 0.009 \mathrm{mmol})$ in THF $(5 \mathrm{~mL})$ was degassed with nitrogen. A $2 \mathrm{M}$ aqueous solution of $\mathrm{K}_{2} \mathrm{CO}_{3}$ $(0.5 \mathrm{~mL})$ was added, and the mixture was heated to $70{ }^{\circ} \mathrm{C}$ overnight. The reaction mixture was quenched with water, and the organic portions were extracted with dichloromethane, washed with brine, and dried over $\mathrm{MgSO}_{4}$. The drying agent was removed via filtration, and the solvent was removed under reduced pressure. The crude product was purified by flash chromatography (silica gel, 3:2 dichloromethane/ hexanes) to yield an orange solid $(0.112 \mathrm{~g}, 0.088 \mathrm{mmol}, 93 \%) .{ }^{1} \mathrm{H}$ NMR (400 MHz, $\left.\mathrm{CDCl}_{3}\right) \delta 9.84(\mathrm{~s}, 1 \mathrm{H}), 7.85(\mathrm{~d}, J=8.1 \mathrm{~Hz}, 2 \mathrm{H})$, $7.61(\mathrm{~s}, 1 \mathrm{H}), 7.50(\mathrm{~d}, J=8.2 \mathrm{~Hz}, 2 \mathrm{H}), 7.20-7.11(\mathrm{~m}, 5 \mathrm{H}), 7.09(\mathrm{~d}, J=$ $8.2 \mathrm{~Hz}, 2 \mathrm{H}), 6.52(\mathrm{~s}, 2 \mathrm{H}), 6.41(\mathrm{~s}, 2 \mathrm{H}), 4.22(\mathrm{tt}, J=10.0,5.0 \mathrm{~Hz}, 1 \mathrm{H})$, $4.07(\mathrm{t}, J=7.2 \mathrm{~Hz}, 4 \mathrm{H}), 4.00(\mathrm{t}, J=7.2 \mathrm{~Hz}, 4 \mathrm{H}), 2.10-1.95(\mathrm{~m}, 2 \mathrm{H})$, $1.95-1.85(\mathrm{~m}, 6 \mathrm{H}), 1.85-1.75(\mathrm{~m}, 4 \mathrm{H}), 1.60-1.52(\mathrm{~m}, 6 \mathrm{H}), 1.52-$ $1.43(\mathrm{~m}, 4 \mathrm{H}), 1.43-1.00(\mathrm{~m}, 50 \mathrm{H}), 0.93-0.86(\mathrm{~m}, 12 \mathrm{H}), 0.80(\mathrm{t}, J=$ $7.0 \mathrm{~Hz}, 6 \mathrm{H}) .{ }^{13} \mathrm{C}\left\{{ }^{1} \mathrm{H}\right\} \mathrm{NMR}\left(100 \mathrm{MHz}, \mathrm{CDCl}_{3}\right) \delta 182.8,160.0,156.6$, $155.6,154.2,149.2,148.6,147.7,145.0,142.8,139.4,134.3,131.9$, $127.6,126.4,124.1,123.7,123.0,122.5,119.8,118.8,113.6,106.0$, $100.0,97.9,68.4,68.0,60.3,47.3,35.1,31.7,31.64,31.58,29.4,29.0$, $27.2,26.9,26.6,26.0,25.8,22.7,22.6,22.6,14.1,14.0$ (one aromatic resonance not observed due to overlap). HRMS (ESI): $\mathrm{m} / z$ calcd for $\mathrm{C}_{82} \mathrm{H}_{109} \mathrm{~N}_{2} \mathrm{O}_{5} \mathrm{~S}_{2}\left([\mathrm{M}+\mathrm{H}]^{+}\right)$: 1265.7778. Found: 1265.7753. Anal. Calcd. for $\mathrm{C}_{82} \mathrm{H}_{108} \mathrm{~N}_{2} \mathrm{O}_{5} \mathrm{~S}_{2} \cdot 1 / 2 \mathrm{H}_{2} \mathrm{O}: \mathrm{C}, 77.25 ; \mathrm{H}, 8.62 ; \mathrm{N}, 2.20$. Found: C, 77.06; H, 8.70; N, 2.14.

LP225. To a solution of $5 \mathrm{a}(0.085 \mathrm{~g}, 0.072 \mathrm{mmol})$ and cyanoacetic acid $(0.018 \mathrm{~g}, 0.215 \mathrm{mmol}, 3.0$ equiv) in chloroform $(1.5 \mathrm{~mL})$ was added piperidine $(0.043 \mathrm{~g}, 0.502 \mathrm{mmol}, 7.0$ equiv). After stirring at 80 ${ }^{\circ} \mathrm{C}$ overnight, the reaction mixture was diluted with dichloromethane $(20 \mathrm{~mL})$ and acidified with $2 \mathrm{M}$ aqueous $\mathrm{HCl}(20 \mathrm{~mL})$. After $5 \mathrm{~min}$ of vigorous stirring, the reaction mixture changed from bright red to dark purple. The organic portions were extracted carefully with dichloromethane and washed with brine, and the solvent was removed under reduced pressure. The crude product was purified by flash chromatography (silica gel) eluting sequentially with dichloromethane, a solution of $5 \%$ methanol in dichloromethane, and a solution of $5 \%$ methanol and $0.1 \%$ acetic acid in dichloromethane to collect a bright red band. The collected fraction was washed with water to remove traces of acetic acid, and the solvent was removed under reduced pressure to yield a shiny purple solid $(0.081 \mathrm{~g}, 0.065 \mathrm{mmol}, 90 \%) .{ }^{1} \mathrm{H}$ NMR $\left(400 \mathrm{MHz},\left(\mathrm{CD}_{3}\right)_{2} \mathrm{CO} / \mathrm{C}_{5} \mathrm{D}_{5} \mathrm{~N}\right) \delta 8.50$ (br. s, $\left.1 \mathrm{H}\right), 8.12$ (br. s, $1 \mathrm{H}), 7.74-7.65(\mathrm{~m}, 3 \mathrm{H}), 7.53(\mathrm{~d}, J=8.2 \mathrm{~Hz}, 4 \mathrm{H}), 7.27(\mathrm{~d}, J=8.2 \mathrm{~Hz}$, $2 \mathrm{H}), 7.21-7.09(\mathrm{~m}, 6 \mathrm{H}), 6.65(\mathrm{~s}, 2 \mathrm{H}), 6.58(\mathrm{~d}, J=8.0 \mathrm{~Hz}, 2 \mathrm{H}), 4.55$ $(\mathrm{tt}, J=10.0,5.0 \mathrm{~Hz}, 1 \mathrm{H}), 4.02(\mathrm{t}, J=6.4 \mathrm{~Hz}, 8 \mathrm{H}), 2.27-2.12(\mathrm{~m}, 2 \mathrm{H})$, $2.12-2.00(\mathrm{~m}, 4 \mathrm{H}), 2.00-1.90(\mathrm{~m}, 2 \mathrm{H}), 1.84-1.66(\mathrm{~m}, 8 \mathrm{H}), 1.54-$ $1.40(\mathrm{~m}, 8 \mathrm{H}), 1.38-1.12(\mathrm{~m}, 28 \mathrm{H}), 0.91(\mathrm{t}, J=7.0 \mathrm{~Hz}, 6 \mathrm{H}), 0.86(\mathrm{t}, J$ $=7.0 \mathrm{~Hz}, 6 \mathrm{H}), 0.77(\mathrm{t}, J=6.8 \mathrm{~Hz}, 6 \mathrm{H}) .{ }^{13} \mathrm{C}\left\{{ }^{1} \mathrm{H}\right\} \mathrm{NMR}(100 \mathrm{MHz}$, $\left.\left(\mathrm{CD}_{3}\right)_{2} \mathrm{CO} / \mathrm{C}_{5} \mathrm{D}_{5} \mathrm{~N}\right) \delta 165.5,160.7,157.9,150.9,148.9,148.6,148.2$, $146.1,144.2,134.9,133.8,131.5,131.2,129.3,127.3,125.5,124.8$, $123.8,123.3,123.1,118.1,114.3,108.1,106.5,101.0,95.6,68.9,68.6$, 60.8, 35.5, 32.4, 32.3, 32.2, 27.2, 26.6, 26.5, 23.3, 23.2, 14.4, 14.34, 14.27. HRMS (ESI): $m / z$ calcd for $\mathrm{C}_{79} \mathrm{H}_{101} \mathrm{~N}_{3} \mathrm{O}_{6} \mathrm{~S}_{2}\left([\mathrm{M}]^{+}\right)$: 1251.7132. Found: 1251.7131. Anal. Calcd. for $\mathrm{C}_{79} \mathrm{H}_{101} \mathrm{~N}_{3} \mathrm{O}_{6} \mathrm{~S}_{2} \cdot 1 /$ $2 \mathrm{H}_{2} \mathrm{O}: \mathrm{C}, 75.20 ; \mathrm{H}, 8.15 ; \mathrm{N}, 3.33$. Found: C, 75.17; H, 8.32; N, 3.28.

LP227. To a solution of $\mathbf{5 b}(0.078 \mathrm{~g}, 0.062 \mathrm{mmol})$ and cyanoacetic acid $(0.016 \mathrm{~g}, 0.185 \mathrm{mmol}, 3.0$ equiv) in chloroform $(1.5 \mathrm{~mL})$ was added piperidine $(0.037 \mathrm{~g}, 0.431 \mathrm{mmol}, 7.0$ equiv). After stirring at 80 ${ }^{\circ} \mathrm{C}$ overnight, the reaction mixture was diluted with dichloromethane $(20 \mathrm{~mL})$ and acidified with $2 \mathrm{M}$ aqueous $\mathrm{HCl}(20 \mathrm{~mL})$. After $5 \mathrm{~min}$ of vigorous stirring, the reaction mixture changed from bright red to dark purple. The organic portions were extracted carefully with dichloromethane and washed with brine, and the solvent was removed under reduced pressure. The crude product was purified by flash chromatography (silica gel) eluting sequentially with dichloromethane, a solution of $5 \%$ methanol in dichloromethane, and a solution of $5 \%$ methanol and $0.1 \%$ acetic acid in dichloromethane to collect a bright red band. The collected fraction was washed with water to remove traces of acetic acid, and the solvent was removed under reduced pressure to yield a shiny purple solid $(0.076 \mathrm{~g}, 0.057 \mathrm{mmol}, 93 \%) .{ }^{1} \mathrm{H}$ NMR $\left(400 \mathrm{MHz},\left(\mathrm{CD}_{3}\right)_{2} \mathrm{CO} / \mathrm{C}_{5} \mathrm{D}_{5} \mathrm{~N}\right) \delta 8.49$ (br. s, $\left.1 \mathrm{H}\right), 8.13$ (br. s, $1 \mathrm{H}), 7.93(\mathrm{~d}, J=8.2 \mathrm{~Hz}, 2 \mathrm{H}), 7.74(\mathrm{~s}, 1 \mathrm{H}), 7.70(\mathrm{~d}, J=8.3 \mathrm{~Hz}, 2 \mathrm{H})$, $7.31(\mathrm{~s}, 2 \mathrm{H}), 7.15(\mathrm{~d}, J=8.2 \mathrm{~Hz}, 2 \mathrm{H}), 7.09(\mathrm{dd}, J=8.1,1.3 \mathrm{~Hz}, 2 \mathrm{H})$, $6.72(\mathrm{~s}, 2 \mathrm{H}), 6.55(\mathrm{~s}, 2 \mathrm{H}), 4.58(\mathrm{tt}, J=10.0,5.0 \mathrm{~Hz}, 1 \mathrm{H}), 4.17(\mathrm{t}, J=$ $6.0 \mathrm{~Hz}, 4 \mathrm{H}), 4.06(\mathrm{t}, J=6.4 \mathrm{~Hz}, 4 \mathrm{H}), 2.26-2.14(\mathrm{~m}, 4 \mathrm{H}), 2.00-1.87$ $(\mathrm{m}, 8 \mathrm{H}$ ), 1.80 (quint., $J=7.2 \mathrm{~Hz}, 4 \mathrm{H}$ ), 1.60 (quint., $J=7.6 \mathrm{~Hz}, 4 \mathrm{H}$ ), 1.50 (quint., $J=7.4 \mathrm{~Hz}, 4 \mathrm{H}), 1.42-1.02(\mathrm{~m}, 40 \mathrm{H}), 0.88-0.0 .82(\mathrm{~m}$, $12 \mathrm{H}), 0.78(\mathrm{t}, J=7.0 \mathrm{~Hz}, 6 \mathrm{H}) .{ }^{13} \mathrm{C}\left\{{ }^{1} \mathrm{H}\right\}$ NMR $(100 \mathrm{MHz}$, $\left.\left(\mathrm{CD}_{3}\right)_{2} \mathrm{CO} / \mathrm{C}_{5} \mathrm{D}_{5} \mathrm{~N}\right) \quad \delta \quad 165.5,161.3,157.4,156.5,155.1,149.5$, $148.8,148.2,145.7,144.2,135.5,133.7,128.6,127.2,125.5,124.5$, $123.9,123.0,120.2,119.7,118.8,118.1,114.1,107.9,101.2,98.7,95.4$, $68.8,68.6,60.8,48.0,35.5,32.4,32.3,27.4,27.2,26.7,26.5,23.30$, 23.27, 23.2, 14.33, 14.27. HRMS (ESI): $m / z$ calcd for $\mathrm{C}_{85} \mathrm{H}_{109} \mathrm{~N}_{3} \mathrm{O}_{6} \mathrm{~S}_{2}$ $\left([\mathrm{M}]^{+}\right)$: 1331.7758. Found: 1331.7742. Anal. Calcd. for $\mathrm{C}_{85} \mathrm{H}_{109} \mathrm{~N}_{3} \mathrm{O}_{6} \mathrm{~S}_{2} \cdot 1 / 2 \mathrm{H}_{2} \mathrm{O}: \mathrm{C}, 76.08 ; \mathrm{H}, 8.26 ; \mathrm{N}, 3.13$. Found: C, 76.15; H, 8.48; N, 3.08.

Optical and Electrochemical Properties. Electronic spectroscopic data were collected in solution using a Hewlett-Packard Diode Array spectrophotometer. Emission spectra were recorded with a Fluorolog Horiba Jobin Yvon model FL-1065. Voltammetric measurements employed a PC controlled AutoLab PSTAT 10 electrochemical workstation and were carried out under anaerobic conditions (argonfilled glove, oxygen, and water $<1 \mathrm{ppm}$ ). Measurements were carried out with $0.1 \mathrm{M} \mathrm{Bu}_{4} \mathrm{NPF}_{6}$ in dichloromethane using a set of glassy carbon, $\mathrm{Pt}$ plate, and $\mathrm{Pt}$ wire as working, counter, and pseudoreference electrodes, respectively. Ferrocene was used as an internal standard $\left(E^{\circ}=+0.69 \mathrm{~V}\right.$ vs NHE $){ }^{20}$

Theoretical Calculations. Full geometry optimizations of compounds LP225 and LP227 in their singlet ground state were performed with density functional theory (DFT) using the M06 functional ${ }^{21}$ with the DGDZVP basis set ${ }^{22,23}$ for all the atoms (double$\zeta$ and polarizations), an ultrafine integration grid, and tight geometrical convergence criteria with the Gaussian 09 package. ${ }^{24}$ All calculations were carried out including implicit solvent effects. Linear-response time-dependent density functional theory (LR-TDDFT) was used in combination with the BMK functional ${ }^{25}$ for the calculations of excitation energies, while ionization energies were computed at the (U)DFT/M06 level. Graphical representation of the molecules and 
their orbitals was obtained with the software VMD v.1.9.0. ${ }^{26}$ For full details concerning the quantum chemical calculations, please see the Supporting Information.

Electrolyte Composition. 4-tert-Butylpyridine (TBP), lithium bis(trifluoromethanesulfonyl)imide (LiTFSI), and the solvents were reagent grade and were used without further purification. Cobalt complexes $\left[\mathrm{Co}(\text { bpy })_{3}\right](\mathrm{TFSI})_{2}$ and $\left[\mathrm{Co}(\text { bpy })_{3}\right](\mathrm{TFSI})_{3}\left(\mathrm{bpy}=2,2^{\prime}\right.$ bipyridine) were synthesized according to reported procedures. ${ }^{17}$ Their bis(trifluoromethane) sulfonimide (TFSI) salt was chosen to improve solubility in acetonitrile. The cobalt electrolyte consists of $0.25 \mathrm{M}\left[\mathrm{Co}(\mathrm{bpy})_{3}\right](\mathrm{TFSI})_{2}, 0.05 \mathrm{M}\left[\mathrm{Co}(\mathrm{bpy})_{3}\right](\mathrm{TFSI})_{3}, 0.25 \mathrm{M}$ TBP, and $0.1 \mathrm{M}$ LiTFSI in acetonitrile.

Solar Cells Preparation. Nanocrystalline $\mathrm{TiO}_{2}$ pastes were prepared using a previously reported procedure. ${ }^{27}$ The $\mathrm{TiO}_{2}$ transparent electrodes were prepared by screen-printing onto fluorine-doped tin oxide (FTO, Solar $4 \mathrm{~mm}$ thickness, $10 \Omega \mathrm{sq}^{-1}$, Nippon Sheet Glass) conducting glass. The film thickness was adjusted to ca. $4.0 \mu \mathrm{m}$ by the number of screen-printing cycles. The screenprinting paste was composed of $\sim 20 \mathrm{~nm}$ diameter anatase particles that gave a mesoporous layer with $\sim 32 \mathrm{~nm}$ pores. To render high power conversion efficiency, an ca. $4 \mu \mathrm{m}$ scattering layer (400 nm diameter, Catalysts \& Chemicals Ind. Co. Ltd. (CCIC), HPW-400) was deposited on the transparent layer. The $8.0 \mu \mathrm{m}$ thick $\mathrm{TiO}_{2}$ electrodes were immersed into a tetrahydrofuran/ethanol solution of the corresponding dye (1:4 ratio, $0.2 \mathrm{mM})$ with 2 equiv of $3 \alpha, 7 \alpha$ dihydroxy- $5 \beta$-cholic acid (chenodeoxycholic acid, CDCA) and kept for $6 \mathrm{~h}$ at room temperature. The dye-adsorbed $\mathrm{TiO}_{2}$ electrode and thermally platinized counter electrode were assembled into a sealed sandwich-type cell with a gap of a hot-melt ionomer film, Surlyn (25 $\mu \mathrm{m}, \mathrm{Du}$ Pont). Devices were completed by filling the electrolyte through a predrilled hole in the counter electrode. A self-adhesive, antireflecting, ultraviolet cutoff film $(\lambda<380 \mathrm{~nm}$, ARKTOP, ASAHI Glass) was attached to the top of the active area to decrease light reflection loss. A black mask $\left(0.159 \mathrm{~mm}^{2}\right)$ that is smaller than the active area of the cells was used in subsequent photovoltaic studies.

Solar Cells Characterization. For photovoltaic measurements of the DSCs, the irradiation source originated from a $450 \mathrm{~W}$ xenon light source (Osram XBO 450) with a filter (Schott 113), whose power was regulated to the AM $1.5 \mathrm{G}$ solar standard by using a reference $\mathrm{Si}$ photodiode equipped with a color-matched filter (KG-3, Schott) to reduce the mismatch in the region of $350-750 \mathrm{~nm}$ between the simulated light and AM $1.5 \mathrm{G}$ to less than $4 \%$. The measurementsettling time between applying a voltage and measuring a current for the $J-V$ characterization of DSCs was fixed to $80 \mathrm{~ms}$. The incident photon-to-collected electron conversion efficiency (IPCE) measurement was plotted as a function of wavelength by using the light from a $300 \mathrm{~W}$ xenon lamp (ILC Technology), which was focused through a Gemini-180 double monochromator (Jobin Yvon) onto the photovoltaic cell under test. A computer-controlled monochromator was incremented through the spectral range $(300-900 \mathrm{~nm})$ to generate a photocurrent action spectrum with a sampling interval of $10 \mathrm{~nm}$ and a current sampling time of $4 \mathrm{~s}$. To reduce scattered light from the edge of the glass electrodes of the dyed $\mathrm{TiO}_{2}$ layer, a light-shading mask was used on the DSCs, so the active area of DSCs was fixed to $0.2 \mathrm{~cm}^{2}$.

Photoinduced Absporption Spectroscopy (PIA). PIA spectra were recorded over 500-1100 nm on transparent devices containing either $\left[\mathrm{Co}^{\mathrm{II} / \mathrm{III}}(\mathrm{bpy})_{3}\right]^{2+/ 3+}$ electrolyte or pure acetonitrile solvent in a 8 $\mu \mathrm{m} \mathrm{TiO}$ film loaded with dyes LP225 or LP227. The samples were excited with a $470 \mathrm{~nm}$ LED, modulated at $9 \mathrm{~Hz}$ (square wave), and driven by the detection lock-in amplifier. White light from a halogen bulb was used as a probe. These spectra allowed identification of the position of oxidized dye species.

Transient Absorption Spectroscopy (TA). Nanosecond laser flash photolysis was applied to samples loaded with dyes LP225 or LP227 (identical to PIA samples). The samples were excited by $7 \mathrm{~ns}$ (fwmh) pulsed laser light produced at a repetition rate of $20 \mathrm{~Hz}$ by an optical parametric oscillator pumped by a frequency-tripled Qswitched Nd:YAG laser. The output excitation wavelength was tuned at $520 \mathrm{~nm}$, and the laser fluence on the sample was kept at a low level $\left(50 \mu \mathrm{J} \mathrm{cm}^{-2}\right.$ per pulse) to ensure that, on average, less than one electron is injected per $\mathrm{TiO}_{2}$ nanoparticle per pulse. The probe light consists of a xenon arc lamp passed through a $665 \mathrm{~nm}$ cutoff filter and a water filter, focused onto the sample and collected in a monochromator at $750 \mathrm{~nm}$. The detector is a fast photomultiplier tube connected to a digital oscilloscope. Typical data are averaged over 1000 laser shots and smoothed using a Savitzky-Golay filter.

\section{RESULTS AND DISCUSSION}

The synthesis of LP225 and LP227 is extremely straightforward, which highlights the appeal of DTP (Scheme 1). The DTP core 2 was prepared from commercially available 3,3'dibromo-2,2'-bithiophene via Buchwald-Hartwig ring closure with tridecan-7-amine. ${ }^{28}$ The key intermediate 4 was synthesized via selective formylation of the DTP core using 1 equiv of lithium diisopropylamine (LDA) in THF at $-78{ }^{\circ} \mathrm{C}$; the resulting lithiated species was converted to 3 through the addition of DMF. This compound was then brominated using 1 equiv of NBS in THF at $-78{ }^{\circ} \mathrm{C}$. Finally, LP225 and LP227 were obtained in two steps from compound $\mathbf{4}$ via Suzuki coupling with the 4,4,5,5-tetramethyl-1,3,2-dioxaborolane derivative of $\mathrm{D} 1^{19}$ or $\mathrm{D} 2{ }^{8}$ respectively, followed by Knoevenagel condensation with cyanoacetic acid.

The optical properties of LP225 and LP227 are strongly solvent and $\mathrm{pH}$-dependent (Figure $\mathrm{S} 1$ and Table S1, Supporting Information) due to changes in the protonation state of the cyanoacrylic acceptor. The absorption spectra in dichloromethane solution very closely resemble that of the protonated form of the dyes and exhibit maxima at 526 and 541 nm, respectively (Figure 1, Table 1, and Table S2, Supporting Information). These values are similar in trend to that observed for Y123 and JF419 with a slight hypsochromic shift.

Linear-response time-dependent density functional theory (LR-TDDFT/BMK/SMD $\left(\mathrm{CH}_{2} \mathrm{Cl}_{2}\right)$ ), based on DFT/M06 geometries of LP225 and LP227, provides absorption spectra in close agreement with the experimental evidence (see
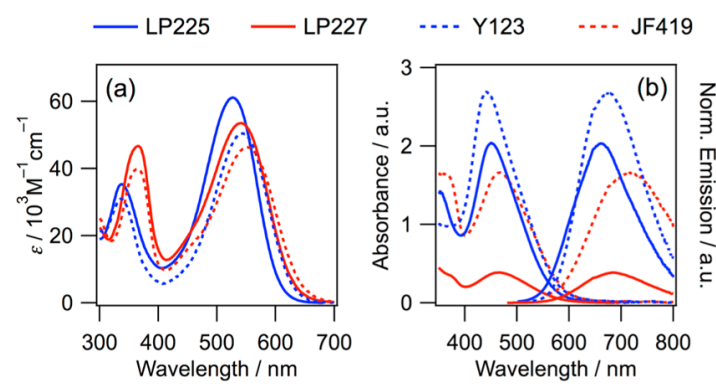

Figure 1. (a) Steady-state absorption spectra measured in dichloromethane solutions and $(\mathrm{b})$ absorption and normalized emission $\left(\lambda_{\mathrm{ex}}=\right.$ $460 \mathrm{~nm}$ ) spectra of $3.3 \mu \mathrm{m}$ thick $\mathrm{TiO}_{2}$ films sensitized with LP225, LP227, Y123, and JF419.

Table 1. Summary of Optical and Electrochemical Data

$\begin{array}{ccccc}\text { dye } & \lambda_{\max } / \mathrm{nm}^{a}\left(\varepsilon / 10^{4} \mathrm{M}^{-1} \mathrm{~cm}^{-1}\right) & E_{0-0}^{b} / \mathrm{eV} & E_{\mathrm{S}+/ \mathrm{S}}^{c} / \mathrm{V} & E_{\mathrm{S} / S^{*}}{ }^{d} / \mathrm{V} \\ \text { LP225 } & 526(5.77) & 2.22 & +0.99 & -1.23 \\ \text { LP227 } & 541(5.26) & 2.15 & +0.84 & -1.31 \\ \mathrm{Y}_{123}{ }^{e} & 542(5.05) & 2.17 & +1.01 & -1.16 \\ \mathrm{JF}_{19}{ }^{e} & 548(4.75) & 2.10 & +0.85 & -1.25\end{array}$

${ }^{a}$ Derived from the absorption in dichloromethane solutions. ${ }^{b}$ Estimated from the intersection point of absorption and normalized emission spectra on $\mathrm{TiO}_{2}$. ${ }^{c} \mathrm{Half}$-wave oxidation potentials measured using cyclic voltammetry and reported vs NHE. ${ }^{d}$ Estimated according to: $E_{S^{+} / S^{*}}=E_{S_{+} / S}-E_{0-0} .{ }^{e}$ From ref 8 . 
Supporting Information for details concerning quantum chemical calculations). In particular, the lowest energy transition $\left(S_{0} \rightarrow S_{1}\right)$ of LP225 is blue-shifted by less than 0.1 $\mathrm{eV}$ compared to the first vertical transition of LP227. The overall hypsochromic shift observed for the DTP relative to the CPDT dyes is also mirrored in the quantum chemical calculations. ${ }^{8}$ The dominant occupied-to-virtual orbital contribution to the $S_{0} \rightarrow S_{1}$ transition is HOMO to LUMO in both cases (82.2\% for LP225 and 81.4\% for LP227), which confirms the intramolecular charge transfer (ICT) character of the main transition (Figure 2).

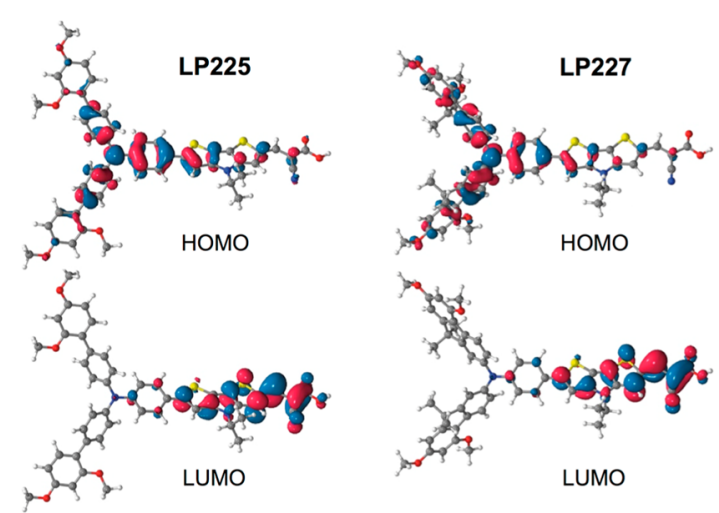

Figure 2. Illustrations of the Kohn-Sham (KS) HOMO and LUMO representing the dominant components of the first vertical transition of LP225 and LP227, computed with LR-TDDFT/BMK/SMD$\left(\mathrm{CH}_{2} \mathrm{Cl}_{2}\right)$. Illustrations of the KS HOMO and LUMO of Y123 and JF419 are virtually identical to LP225 and LP227. The isosurface value in all cases is set to $0.03 \mathrm{au}$.

To more accurately estimate the situation in the device, the absorption and emission were acquired on sensitizers anchored to the $\mathrm{TiO}_{2}$ semiconductor. ${ }^{2}$ The absorption maxima are similar for those dyes that share the same donor moiety, with slightly different band shapes. The emission spectra show marked bathochromic shifts associated with changing the bridge from DTP to CPDT and the donor from D1 to D2. Consequently, the zero-zero transition energy $\left(E_{0-0}\right)$ values for the DTP derivatives are slightly larger relative to those estimated for their CPDT analogues. This observation is consistent with the trends observed for the optical gaps in solution and with an increase in the energy gap for DTP relative to CPDT estimated by DFT calculations. ${ }^{13}$

The energy levels of the sensitizer with respect to the electrochemical potential of the electrolyte and conduction band of $\mathrm{TiO}_{2}(-0.5 \mathrm{~V} \text { vs NHE})^{2}$ also play an important role in the resulting DSC performance. The ground state oxidation potentials $\left(E_{S^{+} / S}\right)$ of LP225 and LP227 are measured at +0.99 and $+0.84 \mathrm{~V}$ vs $\mathrm{NHE}^{20}$ very similar to those of their CPDT counterparts. These values are in good agreement with the trends in ionization energies computed at the (U)DFT/M06 level of theory (Table S2, Supporting Information) and provide ample driving force for regeneration $\left(-\Delta G^{\circ}\right)$ from a $\left[\mathrm{Co}^{\mathrm{II} / \mathrm{III}}(\mathrm{bpy})_{3}\right]^{2+/ 3+}$ electrolyte $(+0.56 \mathrm{~V}$ vs $\mathrm{NHE})$. Using the $E_{S+/ S}$ of the sensitizers and the estimated $E_{0-0}$ value, the excited-state oxidation potentials $\left(E_{S_{+} / S^{*}}\right)$ for the DTP dyes were estimated at -1.23 and $-1.31 \mathrm{~V}$, respectively. The driving force for injection of the photoexcited electron into the $\mathrm{TiO}_{2}$ conduction band is slightly larger than their CPDT analogues, thus ensuring quantitative injection quantum yields into $\mathrm{TiO}_{2}{ }^{8}$
In functional DSCs, a favorable balance between charge recombination and dye regeneration is essential to high efficiency. Their respective time constants $\tau_{\text {rec }}$ and $\tau_{\text {reg }}$ can be quantified using transient absorption (TA) decay measurements (Figure 3). Following excitation at $470 \mathrm{~nm}$, photoinduced absorption signals that appear at ca. 600 and 700-800 $\mathrm{nm}$ are characteristic of ICT band bleaching and triphenylamine radicals, respectively. Time constants are derived from TA decays of the corresponding radical. The absorption traces can be fitted to an exponential decay function $\Delta A(t) \propto A_{0}$ $\exp [-(t / \tau)]$, where $A_{0}$ is the pre-exponential factor and $\tau$ is the characteristic time. ${ }^{29}$ The mean times of charge recombination $\left(\tau_{\text {rec }}\right)$ and oxidized dye regeneration $\left(\tau_{\text {reg }}\right)$ were derived using cells containing an inert or a $\left[\mathrm{Co}^{\mathrm{II} / \mathrm{III}}(\mathrm{bpy})_{3}\right]^{2+/ 3+}$ electrolyte, respectively. Data are reported in Table 2.
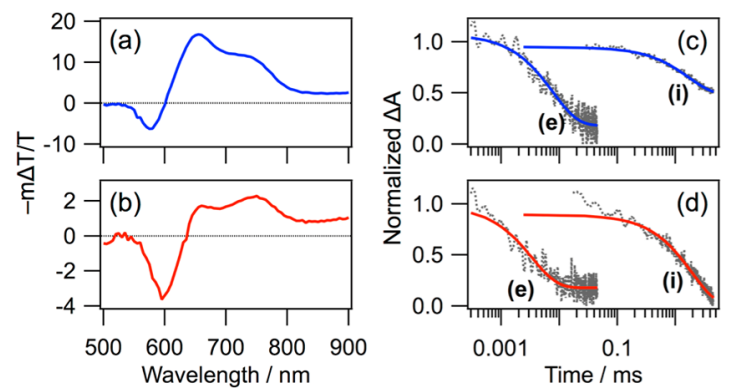

Figure 3. (a, b) PIA following excitation at $470 \mathrm{~nm}$ and (c, d) TA decay traces of $8.0 \mu \mathrm{m}$ thick $\mathrm{TiO}_{2}$ films sensitized with $\mathbf{L P 2 2 5}$ (blue) and LP227 (red). Decays in inert (i) and $\left[\mathrm{Co}^{\mathrm{II} / \mathrm{III}}(\mathrm{bpy})_{3}\right]^{2+/ 3+}(\mathrm{e})$ electrolytes. Laser pulse of $50 \mu \mathrm{J} \mathrm{cm}^{-2}\left(\lambda_{\text {exc }}=530 \mathrm{~nm}\right)$, probe at 750 nm.

Table 2. Kinetic Parameters for Dye Regeneration

$\begin{array}{cccccc}\text { dye } & -\Delta G^{\circ} / \mathrm{eV} & \tau_{\text {rec }} / \mu \mathrm{s} & \tau_{\text {reg }} / \mu \mathrm{s} & \tau_{\text {reg }} / \tau_{\text {rec }} & \Phi_{\text {reg }} / \%^{a} \\ \text { LP225 } & 0.43 & 1700 & 7.7 & 220 & >99 \\ \text { LP227 } & 0.28 & 1900 & 3.4 & 560 & >99 \\ {\mathrm{Y} 123^{b}}^{b} & 0.45 & 550 & 6.8 & 81 & 99 \\ \mathrm{JF}{ }^{b} & 0.29 & 330 & 7.8 & 42 & 98 \\ { }^{a} \Phi_{\text {reg }}=k_{\text {reg }} /\left(k_{\text {reg }}+k_{\text {rec }}\right), \tau_{\mathrm{i}}=1 / k_{\mathrm{i} \cdot}{ }^{b} \text { From ref } 8 . & & \end{array}$

The $\tau_{\text {rec }}$ were estimated at 1.7 and $1.9 \mathrm{~ms}$ for LP225 and LP227, respectively. Notably, these times constants are significantly longer than for the CPDT derivatives, which indicates that electrons injected into the $\mathrm{TiO}_{2}$ recombine slower with the oxidized form of the DTP dyes. Adding the active cobalt(II/III) species to the electrolyte gives accelerated TA decays, with $\tau_{\text {reg }}$ values of 7.7 and $3.4 \mu$ s for LP225 and LP227, respectively. In both cases, the $\tau_{\text {rec }} / \tau_{\text {reg }}$ ratio is large, suggesting extremely favorable charge-transfer kinetics compared to previous systems, ${ }^{16}$ which result in quantitative regeneration quantum yields $\left(\Phi_{\text {reg }}\right)$. The use of DTP instead of CPDT also appears more favorable for the regeneration of the oxidized dye according to this ratio despite $-\Delta G^{\circ}$ similarities.

The incident photon-to-current efficiency (IPCE) spectra were measured on films coated with LP225 and LP227 with an optimized $\left[\mathrm{Co}^{\mathrm{II} / \mathrm{III}}(\mathrm{bpy})_{3}\right]^{2+/ 3+}$ electrolyte composition. The IPCEs exhibit a similar shape for all the dyes with intensity maxima around $80-85 \%$ (Figure $4 a$ ). However, we observe up to a $25 \mathrm{~nm}$ blue-shift in the onset for a given DTP dye compared to its CPDT analogue. The decrease in photon collection is consistent with the estimated $E_{0-0}$ values. The 
Table 3. Detailed Photovoltaic Parameters ${ }^{a}$

\begin{tabular}{|c|c|c|c|c|}
\hline dye & $J_{\mathrm{SC}} / \mathrm{mA} \mathrm{cm}^{-2}$ & $V_{\mathrm{OC}} / \mathrm{mV}$ & $\mathrm{FF}$ & $\eta / \%$ \\
\hline LP225 & $13.4(13.2 \pm 0.2)$ & $901(890 \pm 16)$ & $0.74(0.74 \pm 0.00)$ & $8.86(8.63 \pm 0.21)$ \\
\hline LP227 & $14.1(13.9 \pm 0.2)$ & $811(810 \pm 5)$ & $0.77(0.76 \pm 0.01)$ & $8.72(8.62 \pm 0.09)$ \\
\hline $\mathrm{Y} 123^{b}$ & 14.1 & 876 & 0.78 & 9.77 \\
\hline $\mathrm{JF} 419^{b}$ & 16.2 & 840 & 0.76 & 10.3 \\
\hline
\end{tabular}

${ }^{a}$ Simulated AM 1.5 G conditions. Average values are based on three replicate measurements. ${ }^{b}$ From ref 8.

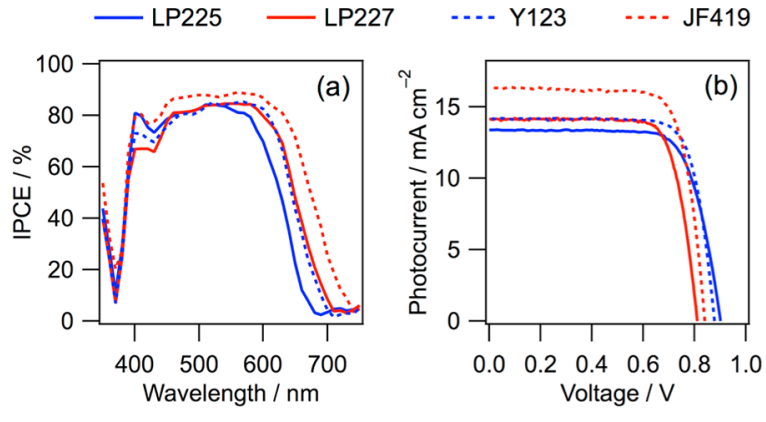

Figure 4. (a) Photocurrent action spectra of mesoscopic solar cells with $\left[\mathrm{Co}^{\mathrm{II} / \mathrm{III}}(\mathrm{bpy})_{3}\right]^{2+/ 3+}$ electrolyte and (b) $J-V$ characteristics measured under simulated AM $1.5 \mathrm{G}$ full sun illumination $(100 \mathrm{~mW}$ $\mathrm{cm}^{-2}$ ).

solar-to-electricity conversion efficiencies of these DSCs were evaluated by recording the $J-V$ characteristics under simulated AM 1.5 G illumination (Figure 4b). As expected from integration of the IPCE, the photocurrent densities $\left(J_{\mathrm{SC}}\right)$ measured for the DTP dyes are ca. $1-2 \mathrm{~mA} \mathrm{~cm}^{-2}$ lower than for their CPDT analogues. On the other hand, marked differences in $V_{\mathrm{OC}}$ are observed in Table 3, where dyes assembled with the D1 donor tend to exhibit higher values.

These variations may be related to fluctuation in the electron density and/or shifts in the conduction band edge of the $\mathrm{TiO}_{2} \cdot{ }^{30}$ Using transient photocurrent decay measurements, we studied the electron lifetime and capacitance as a function of voltage (Figure 5). The lifetime of electrons injected in the
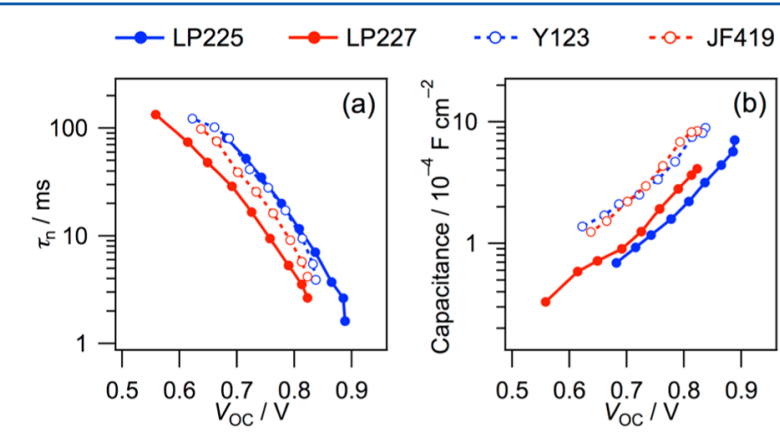

Figure 5. (a) Electron lifetime and (b) capacitance versus open-circuit photovoltage of cells made with $\mathrm{TiO}_{2}$ films coated with LP225, LP227, Y123, and JF419.

$\mathrm{TiO}_{2}\left(\tau_{\mathrm{n}}\right)$ is shorter for LP227 compared to LP225. A similar trend is observed for the CPDT dyes, which indicates that shorter $\tau_{\mathrm{n}}$ are linked to intrinsic limitations of the $\mathrm{D} 2$ donor. However, as expected for LP225 and LP227, the use of a bulky donor prevents the cobalt(III) species from accessing the $\mathrm{TiO}_{2}$ surface, which drastically limits recombination compared to the literature. ${ }^{16}$ Furthermore, decreased capacitance at the same potential bias was observed for the DTP dyes relative to CPDT. This is attributed to a $60-100 \mathrm{mV}$ upward shift of the $\mathrm{TiO}_{2}$ conduction band edge. This effect provides the DTP dyes with higher $V_{\mathrm{OC}}$ relative to CPDT, as exemplified with LP225 and Y123 (the $V_{\text {OC }}$ of LP227 is limited by the electron lifetime).

\section{CONCLUSION}

The conduction band shift observed with LP225 and LP227 should prove particularly advantageous when closing the optical gap of DTP dyes through the use of stronger electron acceptors. Indeed, large $V_{\mathrm{OC}}(>900 \mathrm{mV})$ values are usually obtained with high oxidation redox mediators, which is detrimental to dye regeneration and current densities. ${ }^{16,31}$ As evidenced in this report, the DTP bridge can naturally overcome this issue if favorable charge-transfer kinetics are created upon insulation of the $\mathrm{TiO}_{2}$ surface. Further work is currently underway to improve the spectral response of such DTP dyes.

\section{ASSOCIATED CONTENT}

\section{S Supporting Information}

Characterizing data for experimentally studied compounds; full details of quantum chemical calculations; supplemental figures discussed in the text (PDF). This material is available free of charge via the Internet at http://pubs.acs.org.

\section{AUTHOR INFORMATION}

\section{Corresponding Author}

*E-mail: lauren.polander@epfl.ch; mdkhaja.nazeeruddin@epfl. ch.

\section{Notes}

The authors declare no competing financial interest.

\section{ACKNOWLEDGMENTS}

We acknowledge the European Community's Seventh Framework Programme (FP7/2007-2013) under grant agreement no. 281063 of the Powerweave project for financial support and SSSTC (Sino-Swiss Science and Technology Cooperation). MKN thanks the World Class University program, Korea University funded by the National Research Foundation of Korea (Grant R31-2008-000-10035-0). Support from the Swiss National Science Foundation (Grant No. 200020-130082) and the NCCR-MUST interdisciplinary research program is also gratefully acknowledged.

\section{REFERENCES}

(1) O’Regan, B.; Grätzel, M. Nature 1991, 353, 737-740.

(2) Hagfeldt, A.; Boschloo, G.; Sun, L.; Kloo, L.; Pettersson, H. Chem. Rev. 2010, 110, 6595-6663.

(3) Yu, Q.; Wang, Y.; Yi, Z.; Zu, N.; Zhang, J.; Zhang, M.; Wang, P. ACS Nano 2010, 4, 6032-6038.

(4) Yella, A.; Lee, H. W.; Tsao, H. N.; Yi, C.; Chandiran, A. K.; Nazeeruddin, M. K.; Diau, E. W. G.; Yeh, C. Y.; Zakeeruddin, S. M.; Grätzel, M. Science 2011, 334, 629-634. 
(5) Materials for Nonlinear Optics: Chemical Perspectives; Marder, S. R., Sohn, J. E., Stucky, G. D., Eds.; ACS Symp. Ser.; American Chemical Society: Washington, DC, 1991; Vol. 455.

(6) Mishra, A.; Fischer, M. K. R.; Bäuerle, P. Angew. Chem., Int. Ed. 2009, 48, 2474-2499.

(7) Tsao, H. N.; Yi, C.; Moehl, T.; Yum, J.-H.; Zakeeruddin, S. M.; Nazeeruddin, M. K.; Grätzel, M. ChemSusChem 2011, 4, 591-594.

(8) Yella, A.; Humphry-Baker, R.; Curchod, B. F. E.; Astani, N. A.; Teuscher, J.; Polander, L. E.; Mathew, S.; Tavernelli, I.; Rothlisberger, U.; Moser, J.-E.; Grätzel, M.; Nazeeruddin, M. K.; Frey, J. 2013, $10.1021 / \mathrm{cm} 401593 \mathrm{~b}$.

(9) Brzezinski, J. Z.; Reynolds, J. R. Synthesis 2002, 1053-1056.

(10) Coppo, P.; Cupertino, D. C.; Yeates, S. G.; Turner, M. L. J. Mater. Chem. 2002, 12, 2597-2599.

(11) Ogawa, K.; Rasmussen, S. C. J. Org. Chem. 2003, 68, 29212928.

(12) Ogawa, K.; Rasmussen, S. C. Macromolecules 2006, 39, 17711778.

(13) Odom, S. A.; Lancaster, K.; Beverina, L.; Lefler, K. M.; Thompson, N. J.; Coropceanu, V.; Brédas, J.-L.; Marder, S. R.; Barlow, S. Chem.-Eur. J. 2007, 13, 9637-9646.

(14) Cai, N.; Zhang, J.; Xu, M.; Zhang, M.; Wang, P. Adv. Funct. Mater. 2013, DOI: 10.1002/adfm.201203348.

(15) Mo, H.; Radke, K. R.; Ogawa, K.; Heth, C. L.; Erpelding, B. T.; Rasmussen, S. C. Phys. Chem. Chem. Phys. 2010, 12, 14585.

(16) Xu, M.; Zhang, M.; Pastore, M.; Li, R.; De Angelis, F.; Wang, P. Chem. Sci. 2012, 3, 976-983.

(17) Feldt, S. M.; Gibson, E. A.; Gabrielsson, E.; Sun, L.; Boschloo, G.; Hagfeldt, A. J. Am. Chem. Soc. 2010, 132, 16714-16724.

(18) Feldt, S. M.; Wang, G.; Boschloo, G.; Hagfeldt, A. J. Phys. Chem. C 2011, 115, 21500-21507.

(19) Gao, P.; Kim, Y. J.; Yum, J.-H.; Holcombe, T. W.; Nazeeruddin, M. K.; Grätzel, M. J. Mater. Chem. A 2013, 1, 5535-5544.

(20) Connelly, N. G.; Geiger, W. E. Chem. Rev. 1996, 96, 877-910.

(21) Zhao, Y.; Truhlar, D. G. Theor. Chim. Acta 2008, 120, 215-241.

(22) Godbout, N.; Salahub, D. R.; Andzelm, J.; Wimmer, E. Can. J. Chem. 1992, 70, 560-571.

(23) Sosa, C.; Andzelm, J.; Elkin, B. C.; Wimmer, E.; Dobbs, K. D.; Dixon, D. A. J. Phys. Chem. 1992, 96, 6630-6636.

(24) Frisch, M. J. T.; Schlegel, H. B.; Scuseria, G. E.; Robb, M. A.; Cheeseman, J. R.; Scalmani, G.; Barone, V.; Mennucci, B.; Petersson, G. A.; Nakatsuji, H.; Caricato, M.; Li, X.; Hratchian, H. P.; Izmaylov, A. F.; Bloino, J.; Zheng, G.; Sonnenberg, J. L.; Hada, M.; Ehara, M.; Toyota, K.; Fukuda, R.; Hasegawa, J.; Ishida, M.; Nakajima, T.; Honda, Y.; Kitao, O.; Nakai, H.; Vreven, T.; Montgomery, J. A., Jr.; Peralta, J. E.; Ogliaro, F.; Bearpark, M.; Heyd, J. J.; Brothers, E.; Kudin, K. N.; Staroverov, V. N.; Kobayashi, R.; Normand, J.; Raghavachari, K.; Rendell, A.; Burant, J. C.; Iyengar, S. S.; Tomasi, J.; Cossi, M.; Rega, N.; Millam, N. J.; Klene, M.; Knox, J. E.; Cross, J. B.; Bakken, V.; Adamo, C.; Jaramillo, J.; Gomperts, R.; Stratmann, R. E.; Yazyev, O.; Austin, A. J.; Cammi, R.; Pomelli, C.; Ochterski, J. W.; Martin, R. L.; Morokuma, K.; Zakrezewski, V. G.; Voth, G. A.; Salvador, P.; Dannenberg, J. J.; Dapprich, S.; Daniels, A. D.; Farkas, O.; Foresman, J. B.; Ortiz, J. V.; Cioslowski, J.; Fox, D. J. Gaussian 09; Gaussian, Inc.: Wallingford CT, 2009.

(25) Boese, A. D.; Martin, J. M. L. J. Chem. Phys. 2004, 121, 34053416.

(26) Humphrey, W.; Dalke, A.; Schulten, K. J. Mol. Graph. 1996, 14, 33-38.

(27) Ito, S.; Murakami, T. N.; Comte, P.; Liska, P.; Grätzel, C.; Nazeeruddin, M. K.; Grätzel, M. Thin Solid Films 2008, 516, 46134619.

(28) Koeckelberghs, G.; De Cremer, L.; Vanormelingen, W.; (null); Verbiest, T.; Persoons, A.; Samyn, C. Tetrahedron 2005, 61, 687-691.

(29) Anderson, A. Y.; Barnes, P. R.; Durrant, J. R.; O’Regan, B. C. J. Phys. Chem. C 2011, 115, 2439-2447.

(30) Barnes, P. R. F.; Miettunen, K.; Li, X.; Anderson, A. Y.; Bessho, T.; Grätzel, M.; O’Regan, B. C. Adv. Mater. 2013, 25, 1881-1922.
(31) Yum, J.-H.; Baranoff, E.; Kessler, F.; Moehl, T.; Ahmad, S.; Bessho, T.; Marchioro, A.; Ghadiri, E.; Moser, J.-E.; Yi, C.; Nazeeruddin, M. K.; Grätzel, M. Nat. Commun. 2012, 3, 631. 